\title{
Upaya Promosi Potensi Wisata Kota Denpasar Berbasis Media sosial
}

\author{
Ni Wayan Rena Mariani ${ }^{1)}$, Anak Agung Gede Wijaya ${ }^{2)}$ \\ Sekolah Tinggi Pariwisata Bali Internasional \\ E-mail :wynrena@stpbi.ac.id ${ }^{1)}$
}

\begin{abstract}
Marketing activities for tourism changes along with the development of the use of social media in the community. Traditional marketing methods that were used in marketing activities began to be shifted by digital marketing methods. One type of digital marketing method is social media marketing. Tourism official of denpasar cooperating with the Bali Tourism Board, and the Regional Tourism Promotion Agency uses social media in an effort to promote the tourism potencial of the city of Denpasar. The use of social media is very minimal in 2016 and 2017 to promote the tourism potential of the city of Denpasar. This Situation is not in line with the strategic plan of tourism official of Denpasar for 2011-2015 which states that promotion is carried out involving Information Technology. Mariani (2016) mentions that social media is very helpful in promoting a previously unknown tourist attraction into a favorite tourist attraction. When the use of social media that is very minimal by the manager, the promotion is declared successful. It is caused the strength of the content created by users of social media to introduce this attraction to other social media users. The purpose of this study is to find out the efforts made by the government in promoting tourism potential by utilizing social media. The research using quantitative and qualitative data. Quantitative data consist of number of posts, number of followers, number of likes. Qualitative data consist of social media content and data of interviews with sources. This research is a qualitative study with a case study approach. This research concludes that several social media-based promotion efforts have been carried out, namely greeting social media users through image and video content, inviting the public to attend certain tourism activities, involving social media users, and informing the calendar of events at the beginning of each month.
\end{abstract}

Keywords: : Marketing, Tourism Destination, Social Media

Abstrak - Kegiatan pemasaran tujuan wisata mengalami perubahan seiring dengan berkembangnya penggunaan media sosial di masyarakat. Metode pemasaran Tradisional yang dulu digunakan dalam kegiatan pemasaran mulai digeser oleh metode pemasaran digital. Salah satu jenis metode pemasaran digital adalah Pemasaran media sosial. Dinas Pariwisata Denpasar bekerja sama dengan Bali Tourism Board, dan Badan Promosi Pariwisata Daerah menggunakan media sosial dalam upaya untuk mempromosikan potensi wisata kota Denpasar. Pemanfaatan media sosial yang sangat minim pada tahun 2016 dan 2017 untuk mempromosikan potensi wisata kota denpasar tidak sejalan dengan Rencana strategis satuan kerja perangkat daerah dinas pariwisata kota denpasar Tahun 2011-2015 yang menyebutkan bahwa promosi dilaksanakan dengan melibatkan Teknologi Informasi. Mariani (2016) menyebutkan bahwa media sosial sangat membantu promosi sebuah objek wisata yang sebelumnya tidak dikenal menjadi sebuah objek wisata yang ramai dikunjungi. Dengan pemanfaatan media sosial yang sangat minim oleh pengelola, promosi dinyatakan berhasil. Hal ini disebabkan kekuatan content yang dibuat oleh para pengguna media sosial untuk memperkenalkan objek wisata ini kepada pengguna media sosial yang lain. Tujuan penelitian ini adalah untuk mengetahui upayaupaya yang dilakukan pemerintah dalam mempromosikan potensi wisata dengan memanfaatkan media sosial. Data penelitian yang digunakan adalah data kuantitatif dan kuliatatif. Data kuantitatif yang digunakan adalah jumlah posting, jumlah follower,jumlah likes. Data kualitatif berupa konten media sosial dan hasil wawancara dengannarasumber. Penelitian ini merupakan merupakan penelitian kualitatif dengan pendekatan case study. Penelitian ini menyimpulkan bahwa beberapa upaya promosi berbasis media sosial telah dilakukan yaitu menyapa pengguna media sosial melalui content gambar dan video, mengundang masyarakat untuk hadir dalam kegiataan wisata tertentu, melibatkan masyarakat pengguna media sosial, dan menginformasikan calender of event disetiap awal bulan.

Kata kunci: Pemasaran, Destinasi Wisata, Media Sosial

\subsection{Latar Belakang}

Perkembangan teknologi komunikasi nirkabel menyebabkan teknologi internet dapat dinikmati dimana saja dengan harga yang tidak terlalu mahal. Pemanfaatan internet dengan cara mudah ini, memicu semua pihak untuk berlomba-lomba membagi informasi kepada masyarakat luas. Pihak-pihak ini berlomba- lomba membangun sebuah media untuk berbagi informasi pada masyarakat. Website adalah salah satu media yang digunakan untuk berbagi informasi. Website yang pertama dibuat oleh sebuah organisasi di eropa yang memiliki fokus pada penelitian nuklir pada tahun 1989 di Jenewa Swiss (Reid, 2006). Pada awal Januari tahun 2007 diperkirakan ada 34 bahasa yang 
digunakan untuk membuat web site dan diakses lebih dari 1 triliun orang (O' Brien, 2011).

Perkembangan website mempengaruhi perilaku masyarakat dunia. Kebutuhan sosial dalam hal komunikasi dapat mereka lakukan melalui teknologi internet. Teknologi internet memungkinkan setiap orang yang berjauhan bertukar informasi dengan cepat. Kebutuhan berkomunikasi tidak lagi dihalangi dengan jarak. Perubahan perilaku ini berdampak munculnya berbagai aplikasi berbasis internet untuk memenuhi kebutuhan berkomunikasi. Aplikasi yang dikembangkan antara lain email, aplikasi chating, Video Chating memungkinkan dua orang yang berada di dua tempat yang berjauhan dapat melakukan komunikasi seperti berkomunikasi secara langsung.

Trend komunikasi berbasis internet ini tidak hanya berdampak secara pribadi bagi kehidupan seseorang, tetapi juga sangat berdampak terhadap aktivitas bisnis. Dampak internet terhadap aktivitas bisnis ditandai dengan munculnya web first mall, virtual bank, dan online Pizza pada tahun 1994 (Dave, 2009). Web ini memungkinkan penggunanya berbelanja atau melakukan transaksi secara online melalui internet. Transaksi online memungkinkan pemilik produk ataupun layanan dapat menyentuh pelanggan secara langsung tanpa melalui perantara. Hal ini berarti pengurangan biaya distribusi. Pihak customer juga diuntungkan dengan transaksi online ini. Pelanggan tidak harus keluar rumah untuk berbelanja. Pelanggan tidak memerlukan banyak tenaga untuk memilih barang belanjaan. Tidak perlu keluar masuk toko untuk mencari barang yang dirasa cocok, karena customer dapat mencari produk atau layanan yang diinginkan melalui fitur yang dimiliki oleh web.

Web versi yang ke-2 mulai dikenal pada tahun 2000. Perkembangan web versi ke-2 mengakomodir pengembangan social networking (Dave, 2009). Social networking adalah Teknologi yang memungkinkan orangorang dapat berkomunikasi, berbagi informasi, dan membentuk komunitas online. Banyak generasi muda bahkan para profesional menggunakan media sosial sebagai wadah untuk membagi kehidupan mereka kepada komunitas online mereka. Setiap kegiatan, setiap ide, dibagi lewat susunan kata ataupun dalam bentuk gambar melalui sosial networking.

Perkembangan media sosial berdampak terhadap metode pemasaran produk maupun jasa. Perusahaan menggunakan media sosial sebagai salah satu alat untuk mengenalkan produk ataupun jasa yang diproduksinya. Media sosial dipakai untuk mengenalkan perusahaan kepada customer ataupun calon customer. Customer menggunakan media sosial untuk mencari informasi tentang produk yang mereka perlukan. Customer dapat berbagi pengalaman dengan customer lainnya mengenai produk yang mereka beli.

Metode pemasaran melalui media sosial mempengaruhi pemasaran bidang pariwisata. Metode pemasaran melalui media sosial memungkinkan sebuah tujuan wisata baru menjadi tujuan wista yang ramai pengunjung. Seperti contohnya sebuah tujuan wisata "Hidden canyon" yang berlokasi di guwang Sukawati Gianyar. Pemasaran daerah tujuan wisata ini belum dikelola secara profesional. Tujuan wisata ini dikenal oleh masyarakat umum melalui media sosial seperti facebook, twitter dan media sosial lainnya (Mariani, 2016).

Dinas Pariwisata kota denpasar mengelola beberapa tujuan wisata diantaranya Monumen Bajra sandi dan Kawasan Heritage Gajah Mada. Dinas pariwisata kota denpasar memiliki kendala dalam memperkenalkan potensi wisata di kota denpasar. Hal ini tertuang dalam Rencana strategis satuan kerja perangkat daerah dinas pariwisata kota denpasar Tahun 2011-2015. Dalam rencana strategis tersebut, Dinas pariwisata kota denpasar merencanakan pengembangan program pemasaran dengan memanfaatkan teknologi informasi. Rencana strategis tersebut telah dilaksanakan dan hasil yang diharapkan adalah promosi tujuan wisata kota denpasar dilakukan dengan memanfaatkan teknologi informasi.

Website dinas pariwisata kota denpasar dapat diakses tetapi masih memiliki informasi yang sangat sedikit tentang potensi wisata di kota denpasar. Dinas pariwisata kota denpasar juga telah memiliki akun facebook yang dikelola sendiri oleh dinas pariwisata kota denpasar. Postingan terakhir dalam Akun media sosial ini adalah tanggal 25 Februari 2017. Postingan ini berupa ucapan selamat ulang tahun kepada kota denpasar. Hampir setahun sebelumnya yaitu pada tanggal 27 Mei 2016, admin akun ini membuat postingan yang berkaitan dengan promosi potensi wisata. Postinga ini berupa undangan untuk mengunjungi booth dinas pariwisata kota denpasar dalam pameran yang berjudul gebyar wisata budaya nusantara tanggal 25-30 mei 2016. Seminggu sebelumnya admin akun ini membuat postingan mengenai acara "Bali Interhash 2016" yaitu pada tanggal 19 mei 2016. Acara ini dibuka pada tanggal 19 Mei 2016 dan ditutup pada tanggal 22 Mei 2016.

Fakta diatas menunjukkan bahwa promosi potensi wisata melalui akun media sosial facebook ini belum maksimal. Hal ini menjadi topik menarik untuk diteliti lebih lanjut untuk mengetahui upaya dinas pariwisata kota denpasar dalam mengembangkan program pemasaran potensi wisata kota denpasar dengan memanfaatkan teknologi Informasi. Berdasarkan uraian fakta-fakta diatas, maka 
rumusan masalah dalam penelitian ini adalah Bagaimana upaya promosi potensi wisata kota denpasar berbasis media sosial?

\subsection{Kajian Pustaka}

Social Networking adalah teknologi yang memungkinkan orang-orang berkomunikasi, berbagi informasi secara online (Waad Assaad, 2011). Di Indonesia Social Networking disebut sebagai media sosial. Beberapa media sosial yang umum digunakan di Indonesia adalah Facebook, instagram, path, twitter, dan Youtube. Perkembangan media sosial sangat pesat. Masyarakat membutuhkan media sosial untuk tetap terhubung dengan komunitas mereka. Dengan media sosial, masyarakat dapat aktif berinteraksi dalam komunitas mereka tanpa harus memerlukan waktu khusus untuk menghadiri pertemuan komunitas mereka.

Sejak tahun 2008, media sosial menjadi kebutuhan bagi masyarakat. Hal ini menjadi jalan baru bagi pemillik bisnis untuk menjadi lebih dekat dengan masyarakat. Pemiliki bisnis dapat menggunakan media sosial untuk lebih dekat dengan komunitas-komunitas yang ada dalam masyarakat. Informasi produk dan layanan yang dimiliki oleh pemilik bisnis, dapat disampaikan kepada masyarakat melalui media sosial. Media sosial menjadi trend baru dalam bidang pemasaran. Media pemasaran tradisional seperti koran, majalah, dan televisi mulai ditinggalkan oleh para pemilik bisnis. Dalam penelitiannya yang berjudul "Sosial media as a marketing tool : a literature review", Paquette(2013) menyatakan bahwa media sosial adalah jalan bagi pemilik bisnis untuk memperluas jaringan pemasarannya. Kesimpulan dalam penelitiannya menyatakan bahwa media sosial merupakan langkah yang sangat baik bagi pemilik bisnis untuk membuat user experience karena informasi yang tersimpan di media sosial dapat mengembangkan user experience.

Media sosial memungkinkan pemilik bisnis dikenal oleh calon pelanggan maupun pelanggan. Begitu juga sebaliknya pelanggan mengenal produk, dan kemampuan pemilik bisnis dengan baik. Salah satu peran media sosial dalam pemasaran adalah sebagai penyedia informasi mengenai perusahaan dan produk atau jasa yang ditawarkan oleh pemilik bisnis kepada pelanggan (Neti, 2011). Peranan media sosial ini menjadi pemicu pemilik bisnis mengubah ataupun menambahkan dan menggabungkan metode marketing tradisional dengan marketing melalui media sosial.

Pemasaran pada bidang pariwisata juga mengalami perubahan metode marketing dari metode tradisional ke metode marketing dengan media sosial ini. Penelitian yang berjudul "Social media and promotion of tourist destination with negative country image", Kuric(2016) menyatakan bahwa secara umum responden mengatakan sangat tertarik dengan foto dan video tempat wisata yang dibagi (sharing) melalui media sosial. Responden tertarik pada komentar dan promosi pada foto atau video. Responden mengakui bahwa foto dan video yang mereka lihat membuat responden mempertimbangankan tempat wisata yang tidak pernah mereka pikirkan sebelumnya. Foto dan video tersebut memberikan ide tempat wisata yang layak dikunjungi pada liburan berikutnya.

\subsubsection{Media sosial}

Perkembangan teknologi internet pada akhir tahun 1990, membawa perubahan besar terhadap kehidupan manusia. Internet menjadi tren bagi setiap personal maupun bisnis. Perkembangan teknologi internet diikuti dengan berkembang aplikasi-aplikasi yang berbasis jaringan. Seperti misalnya e-mail, instanst messaging yang berbasis teknologi web. Teknologi web yang kemudian dikenal dengan world wide web, adalah sebuah teknologi yang digunakan untuk mendistribusikan informasi dengan cara yang sangat cepat dengan jangkauan yang luas (J.Page \& Joanne, 2014).

Mulai tahun 2000, teknologi web dikembangkan menjadi teknologi web 2.0. Teknologi web 2.0 adalah sebuah Platform yang memungkinkan user berbagi informasi melalui web. User tidak hanya dapat membaca atau menikmati informasi yang diterima dari internet. User juga dapat memberikan komentar terhadap informasi yang diterima. Dengan kata lain, teknologi web 2.0 memungkinkan terjadinya komunikasi dua arah. Teknologi inilah yang menjadi dasar dikembangkannya sosial network atau lebih dikenal dengan media sosial. Sosial network atau media sosial adalah sebuah teknologi yang memungkinkan user atau pengguna dapat berperan aktif dalam pendistribusian informasi. Media sosial memungkinkan pengguna dapat berbagi (sharing). Informasi yang ada dapat ditambahkan oleh pengguna untuk melengkapi informasi yang telah didistribusikan sebelumnya.

Media sosial juga digunakan sebagai media berkomunikasi antara satu pengguna dengan pengguna yang lain. Media sosial dapat dikategorikan menjadi beberapa tipe ( (J.Page \& Joanne, 2014), yaitu : (1) Social News Site, (2) Social Bookmarking sites, (3) Social Networking, (4) Social Media Sharing, (5) Social Knowledge, dan (6) Social Gaming.

Masing-masing tipe dari media sosial ini memiliki fungsinya masing-masing. Seperti Sosial networking, media sosial tipe ini memiliki fungsi untuk membentuk komunitas didunia maya, contohnya facebook, Myspace, Linked 
dan lain-lain. Media sosial sharing digunakan sebagai media untuk berbagi antara user, seperti misalnya Youtube, Flickr, Picasa, dan lain-lain

\subsubsection{Media sosial Marketing}

Perkembangan media sosial mengubah gaya hidup masyarakat. Sebelum media sosial berkembang, sebuah komunitas membutuhkan waktu khusus untuk dapat bertemu dan berdiskusi. Kerabat yang jauh membutuhkan waktu bertemu dengan kerabat lainnya untuk berbincang-bincang. Orang-orang yang memerlukan informasi, harus bertanya ke berbagai pihak untuk mendapatkannya. Tetapi setelah media sosial menjadi tren, hal-hal tersebut tidak lagi dilakukan. Sebuah komunitas bisa berdiskusi setiap saat, berbagi informasi, mendapatkan informasi dengan sangat mudah melalui media sosial.

Keadaan ini dimanfaatkan oleh pengelola bisnis dalam mendistribusikan informasi yang perlu didistribusikan baik kepada partner bisnisnya maupun kepada customemya. Pengelola bisnis menggunakan media sosial untuk memperkenalkan produknya kepada calon customemya. Metode marketing tradisional mulai ditinggalkan. Promosi melalui iklan di televisi, brosur maupun flyer serta banner besar di pinggir jalan mulai tergeser. Survey kepuasan pelanggan melalui telepon ataupun email serta surat tidak lagi dilaksanakan. Media sosial menjadi sebuah media yang dapat digunakan untuk menggantikan sebagian dari metode marketing yang dulu pernah dilakukan.

Media sosial dapat menjangkau calon customer yang tinggal ditempat yang berjauhan. Calon customer dapat bertanya dan mendapatkan informasi dari sumber yang tepat. Calon customer mendapatkan informasi yang diperlukan melalui customer lain yang sudah menikmati produk atau layanan dari pengelola bisnis. Sebelum membeli calon customer mendapatkan banyak informasi yang dari sumber yang tepat sehingga calon customer dapat membuat keputusan dengan pertimbangan-pertimbangan yang berdasar pada informasi yang telah diperoleh.

Dalam penelitian Neti (2011) yang berjudul "Social media and its role in marketing" menyatakan bahwa media sosial memungkinkan pemilik bisnis untuk : (1) Berbagi pengetahuan dan kemampuan pemilik bisnis, (2) Mengetahui keinginan pelanggan mereka, (3) Pelanggan dapat membantu pelanggan yang lain, dan (4) Mengikutsertakan calon pelanggan.

Media sosial memungkinkan pemilik bisnis dikenal oleh calon pelanggan maupun pelanggan. Begitu juga sebaliknya pelanggan mengenal produk, dan kemampuan pemilik bisnis dengan baik.
Hasil penelitian ini menyatakan bahwa peran media sosial dalam marketing sangat penting. Beberapa peran media sosial dalam marketing adalah :

1. Sebagai penyedia informasi mengenai perusahaan dan produk atau jasa yang ditawarkan oleh pemilik bisnis kepada pelanggan.

2. Sebagai media untuk membangun hubungan diantara pelanggan dengan masyarakat lainnya sehingga masyarakat yang tidak mengenal produk atau layanan yang disediakan pemilik bisnis dapat mengetahui produk dan layanan yang dimiliki

3. Sebagai media yang mampu membuat pelanggan merasa dekat dengan pemilik bisnis, karena pemilik bisnis tidak hanya berbagi mengenai produk terbaru mereka tetapi pemilik bisnis berbagi hal-hal lain yang terkait dengan bisnis mereka.

4. Sebagai media yang menyatukan para pemilik bisnis. Mereka dapat saling berbagi sesama pemilik bisnis yang mungkin melayani pasar yang sama

5. Sebagai media komunikasi bagi para pelanggan. Pelanggan dapat saling berinteraksi mengenai produk atau layanan yang mereka butuhkan.

6. Secara umum peran media sosial yang disebutkan diatas adalah menghubungkan antara pelanggan dengan pelanggan, pelanggan dengan pemilik bisnis, dan pemilik bisnis dengan pemilik bisnis lainnya.

\subsection{Metodologi}

Penelitian ini adalah penelitian kualitatif dengan pendekatan case study di kota Denpasar. Penelitan ini bersifat exploratif dengan mengadopsi pendekatan induktif dalam mengetahui manfaat media sosial dalam kaitannya dengan aktivitas promosi potensi wisata serta upaya-upaya yang efektif dalam mempromosikan potensi wisata kota denpasar. Untuk menemukan praktik baik pengelolaan media sosial, Penelitian ini menggunakan metode komparatif untuk menemukan teknikteknik yang tepat dalam mengelola media sosial.

Penelitian ini menggunakan data primer dan data sekunder. Data primer yang diperlukan dalam penelitian ini adalah content dari 2 media sosial, fakta-fakta yang terkait dengan upaya yang telah dilakukan serta kendala yang dihadapi dalam mempromosikan potensi wisata kota Denpasar. Data primer lain yang diperlukan adalah kebijakan-kebijkaan terkait pengembangan dan promosi potensi wisata kota denpasar. Kebutuhan data sekunder pada penelitian ini berupa data jenis potensi wisata, jumlah potensi wisata, serta lokasi potensi wisata 
Penelitian ini menggunakan beberapa teknik pengumpulan data. Untuk konten media sosial, teknik pengumpulan datanya menggunakan teknik pengambilan basis data (Jogiyanto, 2008). Teknik pengumpulan data lainnya adalah dengan Focus Group Disscussion dengan beberapa staf dinas pariwisata kota denpasar untuk memperoleh data upaya-upaya yang telah dilakukan serta kendala-kendala yang dihadapi dalam mempromosikan potensi wisata. Teknik wawancara juga digunakan untuk memperoleh data kebijakan-kebijakan yang tekait dengan pengembangan dan promosi potensi wisata di kota denpasar. Wawancara akan dilakukan dengan Kepala dinas pariwisata kota denpasar.

Penelitian ini menggunakan 2 teknik analisis data. Teknik analisis yang pertama adalah konten analisis untuk menganalisis data berupa postingan berita pada media sosial. Teknik analisis ini akan mengambil beberapa sampel postingan berita dari beberapa media sosial yang dikelola oleh dinas pariwisata kota denpasar, serta beberapa sampel dari media sosial yang terbukti dikelola secara efektif dalam mempromosikan sebuah produk ataupun jasa. Teknik analisis yang kedua menggunakan teknik analisis yang dicetuskan oleh wolcott. Teknik analisis data ini terdiri dari 4 tahap (Cresswell, 2013) yaitu :

1. Menganalisis data yang telah dikumpulkan dengan memberi fokus pada informasiinformasi tertentu yang dianggap penting

2. Mengidentifikasi pola dari informasiinformasi tertentu

3. Menyusun kontektualisasi dengan membuat sebuah framework dari literature terkait

4. Menggambarkan temuan penelitian dalam bentuk tabel, diagram, gambar, ataupun kasus perbandingan

Teknik analisis ini digunakan untuk menganalisis informasi-informasi yang ditemukan pada postingan berita di media sosial serta menemukan upaya-upaya terbaik dalam mempromosikan potensi wisata kota denpasar

\subsection{Hasil dan Pembahasan}

Denpasar adalah sebuah kotamadya di provinsi Bali yang juga merupakan ibukota provinsi. Sebagai sebuah ibukota propinsi, perkembangan kota Denpasar sangat cepat. Kota Denpasar adalah sebuah kota yang terbagi menjadi 4 buah kecamatan yaitu Denpasar selatan, Denpasar barat, Denpasar timur dan Denpasar utara. Kota Denpasar memiliki banyak potensi wisata yang mengundang banyak wisatawan untuk datang melihat. Beberapa tempat wisata yang terkenal di Bali, ada di kota Denpasar, antara lain kawasan wisata Sanur, Monumen Bajra Sandi, kawasan heritage gajah mada, museum bali, museum le mayeur, desa kertalangu dan kawasan art center. Kawasan wisata sanur sendiri adalah kawasan wisata yang memiliki tempat-tempat wisata yang banyak dikunjungi wisatawan nusantara maupun wisatawan mancanegara. Pesisir pantai yang dimiliki oleh kawasan ini menjadi daya tarik bagi wisatawan. Dikawasan inilah banyak hotel-hotel berbintang dibangun untuk melengkapi fasilitas akomodasi bagi para wisatawan.

Selain tempat wisata, kota denpasar juga banyak memiliki acara-acara yang menjadi daya tarik wisata. Misalkan sanur village festival, pesta kesenian Bali yang diadakan secara berkala setiap tahunnya. Pesta kesenian bali merupakan agenda tahunan yang diadakan oleh propinsi bali dan diadakan di kawasan art center denpasar. Selain acara sanur village festival dan pesta kesenian bali, acara melasti dan pengerupukan juga menjadi salah satu daya tarik wisata. Acara ini sebenarnya merupakan bagian dari ritual keagamaan masyarakat bali terutama yang beragama hindu. Acara ini adalah bagian dari rangkaian upacara nyepi yang diadakan setiap 1 tahun sekali.

Potensi wisata budaya dan kuliner turut mengundang wisatawan untuk datang di kota denpasar. Wisatawan dapat menikmati budaya bali yang masih sangat kental. Wisatawan yang menyukai kuliner datang dikota denpasar untuk menikmati kuliner bali dan kuliner nusantara. Beberapa upaya yang dilakukan oleh dinas pariwisata kota denpasar adalah dengan membuat booklet yang berisi acara tahunan yang diselenggarakan di kota denpasar. Acara tahunan ini dapat diselenggarakan oleh dinas pariwisata maupun oleh organisasi swadaya masyarakat. Kalender ini di bagikan kepada seluruh instansi pemerintah, industri pariwisata, dan organisasi masyarakat melalui acara-acara yang diadakan oleh dinas pariwisata kota denpasar.

Selain Dinas pariwisata Denpasar, Badan Promosi Pariwisata daerah (BPPD) bali dan bali media melaksanakan beberapa program yang melibatkan masyarakat dalam kegiatan promosi tersebut. BPPD bali dan Bali media mengadakan beberapa kegiatan lomba yang melibatkan masyarakat seperti misalnya mengadakan lomba vlog joy ful denpasar, lomba karikatur dan lomba food Contest. Perlombaan ini melibatkan masyarakat denpasar secara luas. Pemerintah kota dan Propinsi berusaha keras untuk mengajak seluruh masyarakat kota denpasar untuk berpartisipasi dalam mempromosikan potensi wisata kota denpasar. Pemerintah dan masyarakat bahu membahu agar potensi wisata kota denpasar dapat diperkenalkan ke seluruh dunia.

\subsubsection{Media sosial Facebook}

Media sosial facebook yang dimiliki dinas Pariwisata kota denpasar berupa sebuah 
Facebook Page yang memuat posting dan gambar dari beberapa kegiatan yang dilakukan oleh Dinas Pariwisata kota denpasar. Facebook ini memiliki 129 orang Follower, dan 128 likers. Jumlah ini sangat kecil mengingat Facebookpage ini sudah dibuat sejak tahun 2014.

Aktivitas dari media sosial ini sangat tinggi. Banyak berita/post yang diinformasikan melalui facebookpage ini. Bila ditinjau postingan sejak bulan Januari 2018 hingga Agustus 2018, total postingan yang dibuat adalah 117. Pada bulan Januari 2018 ada 12 post yang dibuat oleh operator media sosial ini. Jumlah post setiap bulannya berbeda-beda. Hal ini disebabkan agenda kegiatan pariwisata dan budaya setiap bulan berbeda-beda. Tabel 5.1 menggambarkan jumlah postingan perbulan. Rata-rata jumlah postingan per bulan yang dibuat oleh operator media sosial Dinas Pariwisata kota Denpasar adalah 14.6 postingan. Berarti rata-rata setiap 2 hari, operator melakukan postingan di facebook page ini. Post yang dibuat oleh operator dilakukan secara berkelanjutan. Jumlah post pada tabel 1 tersebar di beberapa tanggal pada setiap bulannya. Hal ini membuat media sosial follower diingatkan terus pada media sosial Dinas pariwisata Kota Denpasar. Setiap Post yang dibuat, akan muncul pada beranda media sosial milik follower. Sehingga setiap informasi yang di-post dibaca oleh follower.

Tabel 1. Jumlah post perbulan pada facebook page Dinas Pariwisata kota Denpasar

\begin{tabular}{|l|l|}
\hline Bulan & Jumlah post \\
\hline Januari 2018 & 12 post \\
\hline Februari 2018 & 17 post \\
\hline Maret 2018 & 8 post \\
\hline April 2018 & 16 post \\
\hline Mei 2018 & 19 post \\
\hline Juni 2018 & 10 post \\
\hline Juli 2018 & 14 post \\
\hline Agustus 2018 & 21 post \\
\hline Jumlah & 117 post \\
\hline Rata-rata & 14.625 post \\
\hline
\end{tabular}

Informasi yang disajikan dalam setiap post pada media sosial facebookpage Dinas pariwisata kota denpasar bermacam-macam. Ada post yang menyajikan informasi terkait tentang kegiatan (event) yang akan diselenggarakan, post yang menyajikan informasi terkait dengan tempat wisata di kota denpasar, post yang menyajikan informasi terkait dengan tempat kuliner di kota denpasar, post yang bertujuan untuk menyapa follower dengan "Selamat Pagi", ucapan selamat ulang tahun kepada tokoh masyarakat kota denpasar, dan post yang bertujuan mengucapkan selamat hari raya nyepi dan hari raya galungan bagi seluruh masyarakat denpasar yang merayakannya.

Beberapa post menyajikan informasi terkait dengan kegiatan/event yang memberikan pilihan kepada masyarakat denpasar dalam memilih kegiatan untuk mengisi hari libur bersama keluarga. Seperti informasi yang dipost pada awal januari 2018 yaitu tanggal 4 januari 2018. Post ini memberikan informasi pendaftaran lomba terkait festival legong keraton lasem IV. Informasi ini juga membuat masyarakat mengetahui kegiatan yang diadakan di kota denpasar. Gambar 1 merupakan contoh post yang menyajikan informasi terkait kegiatan yang sedang berlangsung di kota denpasar.

Post yang menyajikan informasi tentang kegiatan wisata yang sedang berlangsung $\mathrm{d}$ kota denpasar antara lain festival legong, acara sanur village festival, lomba layang-layang, pesta kesenian bali, aksi budaya omed-omedan di sesetan dan kegiatan lomba yang melibatkan masyarakat umum. Beberapa post juga memberikan informasi terkait undangan untuk menyaksikan pameran lukisan yang diberi tema "The Dynamic Heritage". Event ini diadakan di santrian Gallery. Konten dari post ini berbentuk gambar dan video yang sangat digemari oleh pengguna media sosial. Oleh karena itu informasi akan sampai dengan mudah kepada masyarakat pengguna media sosial.

Selain konten yang berisi informasi kegiatan, facebook page dinas pariwiata kota denpasar juga membuat post yang menyajikan informasi terkait dengan informasi tempat kuliner di kota denpasar. Seperti post yang di buat pada tanggal 21 April 2018. Post ini menyajikan informasi terkait dengan tempat makan yang menyajikan masakan bali yaitu di pasar malam kumbasari. Gambar 2 adalah salah satu post yang memberikan informasi tempat kuliner yang bisa dinikmati.

Informasi sejenis ini banyak dibuat oleh operator media sosial dinas pariwisata kota denpasar. Informasi yang disajikan antara lain pusat kuliner di pasar malam kereneng, pasar malam di sanur, dan tempat kuliner yang dibuat sebagai tempat bagi anak muda untuk bertemu dan bersosialisasi. Informasi ini disertai dengan gambar yang diambil secara profesional oleh fotographer. Gambar-gambar yang disajikan membuat orang yang melihatnya ingin mengunjungi tempat kuliner tersebut dan merasakan makanan yang disajikan ditempat tersebut.

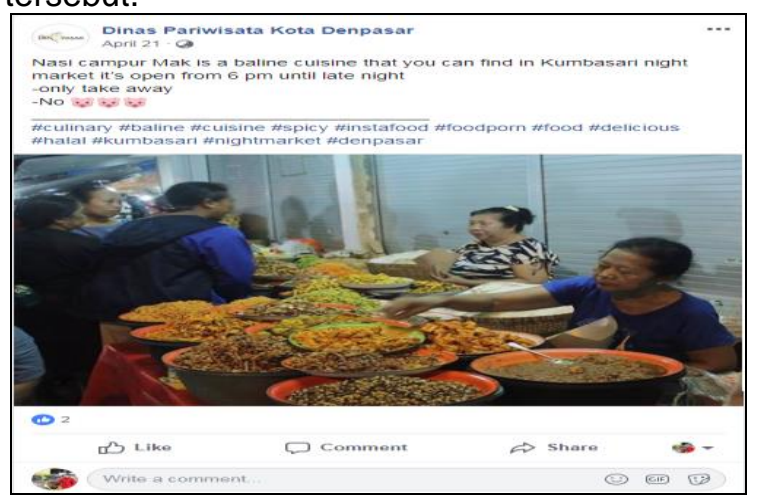


Gambar 1. Post yang menyajikan informasi tempat menikmati Kuliner di kote Denpasar

Untuk tetap mempertahankan eksistensi dalam media sosial, operator media sosial ini, banyak membuat post yang isinya hanya sekedar mengucapkan "Good Morning", ucapan selamat hari raya seperti, ucapan selamat "Gong Xi Fa Cai" bagi masyarakat yang merayakannya, ucapan selamt hari raya nyepi, dan selamat hari raya galungan, ucapan selamat menunaikan ibadah puasa, serta ucapan hari raya waisak. Setiap post yang dibuat selalu disertai gambar yang menarik. Untuk ucapan selamat hari raya, disertai dengan gambar yang terkait dengan hari raya tersebut. Tetapi yang sangat menarik adalah ucapan selamat pagi yang disertai dengan gambar tempat wisata yan ada didenpasar. Seperti post yang dipublikasika pada tanggal 10 Juni 2018. Post ini menyapa pengguna media sosial dengan ucapan selamat pagi. Tetapi gambar yang menyertai ucapan ini adalah gambar dari salah satu pantai yang berlokasi di sanur. Gambar ini dipublikasikan untuk mengenalkan beberapa tempat wisata yang direkomendasikan oleh dinas pariwisata kota denpasar.

Post sejenis banyak dipublikasikan dengan disertai gambar dari beberapa tempat wisata di kota denpasar. Secara tidak langsung, ucapan ini juga mempromosikan beberapa tempat wisata di kota denpasar. Gambar 3 adalah post yang menyapa pengguna media sosial dengan menyertakan gambar pantai sanur.

Selain ucapan selamat pagi yang mempromosikan tempat wisata, ada juga beberapa informasi yang dipublikasikan memang bertujuan untuk mengenalkan tempat wisata yang ada di kota denpasar. Seperti post yang menyajikan informasi tempat wisata di serangan, tempat wisata hutan mangrove, pasar kumbasari, museum lemayeur, janggan park tempat rekreasi keluarga, subak sembung peguyangan, dan beberapa tempat lain di kota denpasar. Salah satu post yang menyertai gambar tempat wisata yang sangat indah adalah informasi yang dipublikasikan pada tanggal 23 april 2018. Post ini menyajikan informasi tempat wisata yaitu jembatan serangan yang menghubungkan pulau serangan dan pulau bali. Kemampuan fotographer dalam menentukan sudut pengambilan gambar membuat gambar ini sangat indah untuk dinikmati. Gambar yang indah akan menarik minat masyarakat untuk berkunjung ke tempat tersebut.

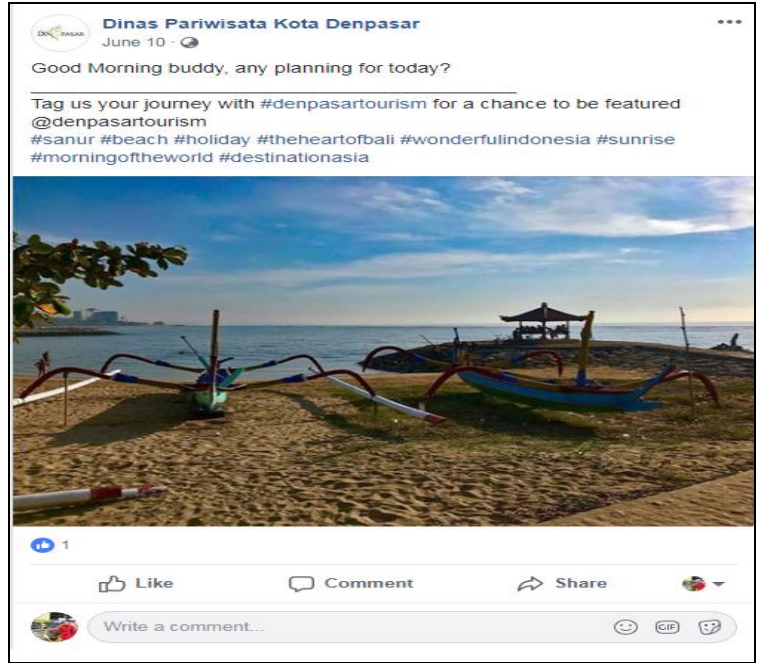

Gambar 2. Post yang menyajikan ucapan selamat pagi disertai dengan gambar objek wisata di kota denpasar

Upaya promosi berbasis media sosial facebook telah dilakukan dengan baik oleh dinas pariwisata kota denpasar. Tetapi tidak banyak tanggapan yang diberikan untuk setiap informasi yang dibagikan. Apabila diperhatikan pada setiap post yang dipublikasikan, ada ajakan untuk berbagi pengalaman dengan yang di -tag ke media sosial milik dinas pariwisata kota denpasar. Begitu juga dengan penggunaan hashtag (\#) pada setiap post yang dibuat. Hal ini sangat membantu pengguna media sosial dalam mencari informasi tentang kota denpasar.

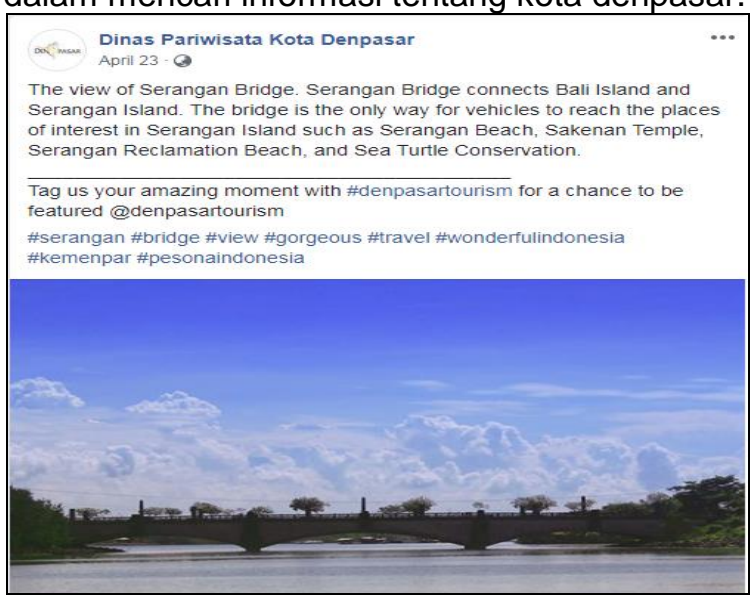

Gambar 3. Post yang menyajikan panorama yang bisa dinikmati dari tempat wisata di kota denpasar

\subsubsection{Instagram}

Dinas pariwisata Denpasar menggunakan media sosial instagram dalam upaya untuk mempromosikan potensi wisata kota denpasar. Hingga bulan september 2018, jumlah followers dari media sosial instagram milik dinas pariwisata kota denpasar sebanyak 841 followers, dengan 228 post yang sudah dibuat. Gambar 1 menunjukkan laman instagram milik dinas pariwisata kota denpasar. 
Instagram dinas pariwisata kota denpasar diberi nama denpasartourism. Banyak follower memungkinkan setiap post yang dibuat akan mendapat respon lebih banyak dari pengguna media sosial. Semakin banyak Follower akan mengakibatkan post

Bila diperhatikan disetiap post yang dibuat, instagram milik dinas kota denpasar mendapat respon lebih banyak daripada post yang dibuat dan dipublikasikan di laman facebook. Informasi yang dibagikan sebagian besar sama dengan informasi yang dibagikan pada facebook page. Beberapa gambar yang disajikan dalam setiap post yang dipublikasikan melalui facebook page juga dipublikasikan melalui instagram. jumlah post yang dipubllikasikan sejak awal tahun 2018 sebanyak 160 buah post. Hal ini menyiratkan bahwa dua media sosial ini terhubung satu sama lain. Ketika operator berbagi informasi lewat instagram, secara otomatis tautan tersebut akan di-post juga melalui media sosial.

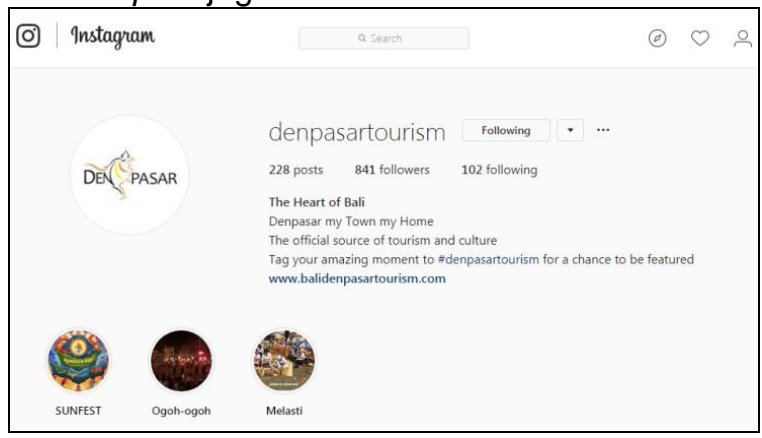

Gambar 4. Laman instagram milik dinas pariwisata kota denpasar

Isi setiap post dalam media sosial instagram milik Dinas Pariwisata kota denpasar, menyajikan informasi yang sejenis dengan facebookpage. Post yang dibuat oleh operator media sosial instagram Dinas Pariwisata Kota Denpasar banyak menginformasikan tentang tempat wisata di kota denpasar, kegiatan/event yang sedang berlangsung di kota denpasar, serta beberapa tempat kuliner yang dapat dikunjungi di kota denpasar. Setiap post yang dibuat disertai dengan gambar dan video yang membuat pengguna media sosial instagram tertarik untuk menyimak informasi yang disajikan dalam media sosial instagram tersebut.

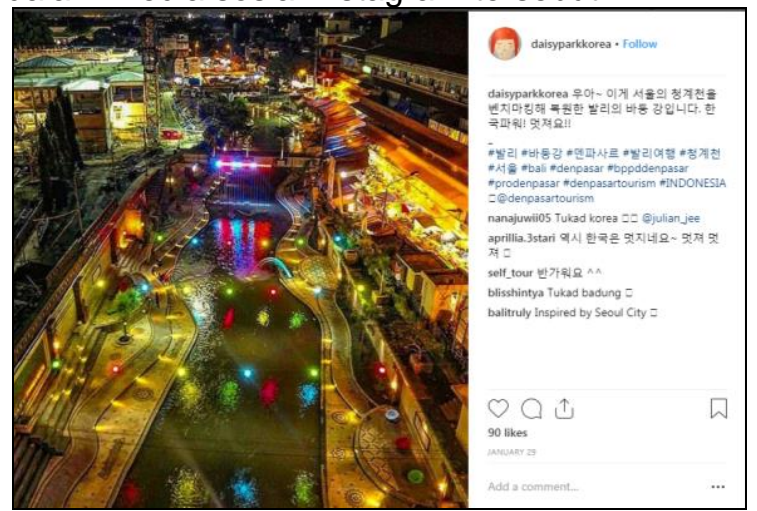

Gambar 5. Salah satu post yang dibuat pemilik akun media sosial yang menggunakan hashtag(\#) DenpasarTourism

Penggunaan hashtag dan fitur berbagi yang dimiliki media sosial sangat membantu upaya promosi ini. Gambar 6 menunjukkan salah satu akun media sosial membagi gambar yang sangat menarik dan menggunakan hashtag yang sama yang digunakan dalam media sosial instagram milik dinas pariwisata.Dalam postingan ini, pemilik akun media sosial mengunggah foto salah satu tempat wisata yaiu tukad badung yang diambil pada malam hari. Keindahan yang ditampilkan foto ini menarik minat pengguna media sosial untuk melihat secara langsung objek wisata tersebut.

Selain Dinas Pariwisata kota denpasar, Badan Promosi Pariwisata daerah bali dan bali media juga turut berperan aktif dalam mempromosikan potensi wisata kota denpasar. Akun bali media mengungguh sebuah konten tentang ajakan mengikuti loba vlog joyful Denpasar. Hasil Vlog dapat diunggah dengan disertai Hashtag(\#) denpasarmedia dan denpasartourism Ini merupakan salah upaya untuk mempromosikan hal-hal menarik yang ada di denpasar. Hal-hal menarik ini berpotensi menjadi sebuah objek wisata baru yang dapat dinikmati oleh masyarakat dan menjadi alasan bagi masyarakat untu berwisata ke kota denpasar. Gambar 7 menggambarkan unggahan denpasarmedia yang menginformasikan lomba vlog tersebut.

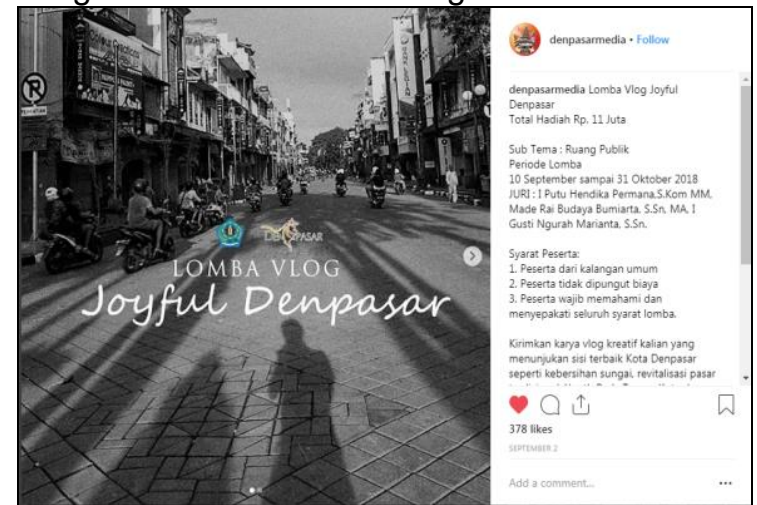

Gambar 6. Salah satu post denpasarMedia yang menyajikan informasi lomba vlog joyful denpasar Informasi yang dipublikasikan pada media sosial instagram lebih banyak mendapat respon dibandingkan informasi yang dipublikasikan melalui media sosial facebook. Gambar 8 merupakan gambar dan informasi yang sama dengan gambar 2 Informasi ini pernah dipublikasikan pada akun media sosial facebook page milik dinas pariwisata kota denpasar pada tanggal 21 april 2018. Pada hari yang sama content ini dipublikasikan melalui akun Instagram milik dinas Pariwisata kota denpasar. Jumlah respon yang diterima sangat jauh berbeda. Pada akun facebook page, informasi 
ini hanya disukai oleh 2 pengguna akun media sosial, sedangkan pada akun instagram, informasi ini disukai oleh 53 pengguna media sosial. Begitu juga dengan jumlah respon pada post lainnya. Rata-rata jumlah respon berupa aksi menyukai / like informasi pada akun instagram dinas pariwisata kota denpasar diatas 15 buah. Bahkan sebuah post bisa mendapat respon like lebih dari 100 pengguna media sosial instagram.

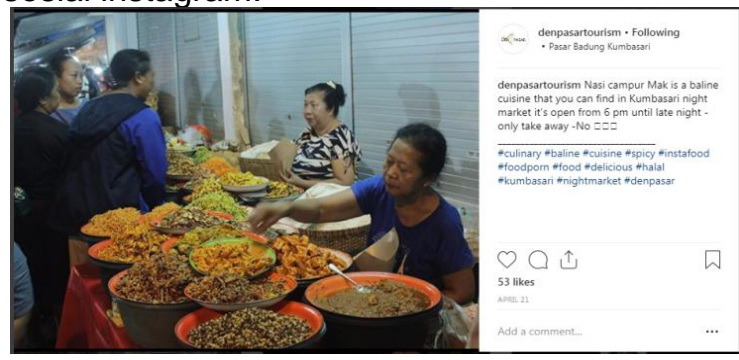

Gambar 7. Salah satu post yang juga diunggah pada media sosial facebook.

Perbedaan jumlah respon yang diperoleh setiap post pada akun instagram dan akun facebook page milik dinas pariwisata kota Denpasar, menunjukkan bahwa publikasi informasi akan lebih efektif menggunakan media sosial instagram dibandingkan dengan media sosial facebook page. Dinas Pariwisata dapat mengetahui respon masyarakat terhadap informasi yang dipublikasikan. Selain itu dengan jumlah follower yang sudah cukup banyak, Dinas pariwisata dapat mempublikasikan informasi-informasi menarik lainnya sehingga jumlah follower dapat bertambah.

\subsection{Kesimpulan}

Dinas pariwisata kota denpasar telah melakukan berbagai upaya untuk mempromosikan potensi wisata kota Denpasar Salah satunya adalah dengan menerbitkan kalender tahunan yang dipublikasikan dalam bentuk booklet. Booklet ini didistribusikan kepada seluruh masyarakat diberbagai acara atau kegiatan yang dilakukan oleh Dinas Pariwisata kota denpasar. Isi booklet ini adalah agenda tahunan kegiatan seni dan budaya yang diadakan di kota denpasar. Kegiatan seni dan budaya ini menjadi salah satu potensi wisata kota denpasar. Beberapa acara yang menjadi kegiatan tahunan seperti pawai ogoh-ogoh pada bulan maret, sanur village festival, denpasar festival, dan beberapa kegiatan yang selalu diadakan setiap tahun.

Selain menerbitkan booklet, dinas Pariwisata kota Denpasar juga bekerjasama dengan Badan Promosi Pariwisata Daerah Bali untuk mempromosikan potensi wisata di kota denpasar. Kegiatan yang dilakukan sebagai bentuk kerjasama antara Dinas Pariwisata kota Denpasar dengan Badan Promosi pariwisata daerah Bali adalah dengan mengadakan beberapa kegiatan lomba fotographi ataupun vlog yang harus diupload dan di-tag ke akun media sosial milik Dinas pariwisata kota denpasar dan badan promosi pariwisata daerah bali.

Upaya yang telah dilakukan dengan melibatkan media sosial sebagai alat promosi, antara lain :

1. Membuat content yang memuat gambar dan video yang menjadi salah satu daya tarik agar pengguna media sosial mendapatkan informasi secara detail

2. Menyapa pengguna media dengan ucapan selamat pagi, atau mengucapkan selamat hari raya kepada masyarakat dengan agamaagama tertentu disertai dengan gambar objek wisata.

3. Mempublikasikan calender of event yang diambil dari materi booklet yang dicetak dan didistribusikan secara offline.

4. Melibatkan masyarakat pengguna media sosial dengan cara mengajak pengguna media sosial untuk berbagi pengelaman mereka berwisata di kota denpasar. Pengguna media sosial juga dilibatkan dengan mengadakan lomba yang hasil lombanya di-post padamedia sosial mereka dan dibagikan degan menambahkan hashtag (\#) atau di-tag secara langsung ke media sosial milik dinas pariwisata kota denpasar.

Kerjasama Dinas Pariwisata Kota Denpasar dengan Badan Promosi Pariwisata Daerah Bali memanfaatkan media sosial dalam mempromosikan potensi wisata kota denpasar. Media sosial yang memiliki kekuatan untuk mempublikasikan informasi secara cepat dan memiliki jangkauan luas, telah dimanfaatkan dengan baik oleh Dinas Pariwisata kota denpasar. Publikasi informasi yang dilakukan secara terus menerus dan berkelanjutan membuat, follower dari media sosial meningkat. Terutama pada akun instagram Dinas Pariwisata kota denpasar. Jumlah follower yang mencapai 800 lebih pengguna media sosial instagram membuat informasi yang dipublikasikan dapat dilihat oleh banyak orang melalui media sosial miliknya. Respon yang diperoleh pada setiap post yang dibuat juga meningkat. Banyak post yang mendapat respon like / disukai lebih dari 30 pengguna akun instagram. Hal ini menandakan bahwa masyarakat tertarik dengan informasi yang disajikan melalui akun media sosial instagram tersebut.

Banyaknya respon yang diperoleh tidak terlepas dari isi informasi tersebut. Setiap informasi yang dipublikasi, terdiri dari sebuah foto atau video yang dibuat secara profesional oleh fotographer dan videographer profesional. Setiap gambar dilengkapi dengan keterangan 
mengenai gambar tersebut serta disertai dengan ajakan untuk berbagi foto-foto perjalanan para wisatawan dengan cara membagi foto-foto tersebut pada media sosial mereka masingmasing dengan menambahkan hastag (\#) denpasartourism.

Daftar Pustaka

[1] Creswell, J. W. (2013). Research Design. California: Sage publications

[2] Dave, C. (2009), E-Bussiness \& ECommerce Management, Strategy Implementation \& Practice, Edinburgh Gate England, Prentice Hall

[3] J.Page, S., \& Joanne, C. (2014). Tourism a Modern Synthesis. Hampshire: Cengage Learning EMEA.

[4] Jogiyanto, HM (2008), Metodologi Penelitian Sistem Informasi, Jogyakarta: Andi Offset

[5] Kuric, N. (2016, February 10). Social Media and promotion of Tourist Destination with negative country image. Switzerland.
[6] Mariani, N. W. (2016). Role of social media in the promotion "Hidden Canyon" Tourism Object. International Conference on Tourism, Gastronomy, and Tourist Destination (p. 78). Jakarta: Atlantis Press.

[7] Neti, S. (2011). Social media and its role in marketing. International Journal of enterprise computing and Bussiness system

[8] Paquette, H. (2013). Social Media as a Marketing Tool : A Literature Review. Major Papers by master of science student, Paper 2.

[9] Reid, B. (2006), Hospitality Marketing Management, New Jersey,John Wiley \& Sons, Inc

[10] Waad Assaad, J. M. (2011). Social Network in Networking Opportunities and Risks. International Journal of Managing Public sector Information and Communication Technologies. 